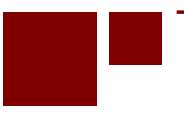

C E N T E R for RETIREMENT RES E A R C H at BOSTON COLLEGE

\title{
HOW MUCH DOES MOTHERHOOD COST WOMEN IN SOCIAL SECURITY BENEFITS?
}

\author{
Matthew S. Rutledge, Alice Zulkarnain, and Sara Ellen King
}

CRR WP 2017-14

October 2017

\author{
Center for Retirement Research at Boston College \\ Hovey House \\ 140 Commonwealth Avenue \\ Chestnut Hill, MA 02467 \\ Tel: 617-552-1762 Fax: 617-552-0191 \\ http://crr.bc.edu
}

Matthew S. Rutledge and Alice Zulkarnain are research economists at the Center for Retirement Research at Boston College (CRR). Sara Ellen King is a research associate at the CRR. The research reported herein was performed pursuant to a grant from the U.S. Social Security Administration (SSA) funded as part of the Retirement Research Consortium. The opinions and conclusions expressed are solely those of the authors and do not represent the opinions or policy of SSA, any agency of the federal government, or Boston College. Neither the United States Government nor any agency thereof, nor any of their employees, makes any warranty, express or implied, or assumes any legal liability or responsibility for the accuracy, completeness, or usefulness of the contents of this report. Reference herein to any specific commercial product, process or service by trade name, trademark, manufacturer, or otherwise does not necessarily constitute or imply endorsement, recommendation or favoring by the United States Government or any agency thereof. The authors thank Caroline van Kimmenaede, Bernard Ho, and Melanie Qing for excellent research assistance.

(C) 2017, Matthew S. Rutledge, Alice Zulkarnain, and Sara Ellen King. All rights reserved. Short sections of text, not to exceed two paragraphs, may be quoted without explicit permission provided that full credit, including $(\subset)$ notice, is given to the source. 


\begin{abstract}
About the Center for Retirement Research
The Center for Retirement Research at Boston College, part of a consortium that includes parallel centers at the University of Michigan and the National Bureau of Economic Research, was established in 1998 through a grant from the Social Security Administration. The Center's mission is to produce first-class research and forge a strong link between the academic community and decision-makers in the public and private sectors around an issue of critical importance to the nation's future. To achieve this mission, the Center sponsors a wide variety of research projects, transmits new findings to a broad audience, trains new scholars, and broadens access to valuable data sources.
\end{abstract}

Center for Retirement Research at Boston College

Hovey House

140 Commonwealth Ave

Chestnut Hill, MA 02467

Tel: 617-552-1762 Fax: 617-552-0191

http://crr.bc.edu

Affiliated Institutions:

The Brookings Institution

Syracuse University

Urban Institute 


\begin{abstract}
The increase in female labor force participation coupled with a higher number of women reaching retirement unmarried has increased the share of women claiming Social Security benefits earned through their own job histories. But they still bear the lion's share of caregiving responsibilities, and the previous literature has provided clear evidence that motherhood reduces earnings during the childbearing and child-rearing years. What remains understudied is the extent to which mothers face lower lifetime earnings and, consequently, lower Social Security income. This paper uses the Health and Retirement Study (HRS) linked to administrative earnings records to answer three questions. First, how much less do mothers earn over their careers compared to childless women, and how much less do they earn for each additional child? Second, how do Social Security benefits differ between mothers and non-mothers? Third, how does each of the existing elements of the Social Security system that indirectly help mothers namely, spousal benefits and the progressivity of the benefit formula - contribute to reducing the motherhood penalty?
\end{abstract}

The paper found that:

- The lifetime earnings of mothers with one child are 28 percent less than the earnings of childless women, all else equal, and each additional child lowers lifetime earnings by another 3 percent.

- When examining Social Security benefits, the motherhood penalty is smaller than the earnings penalty. But mothers with one child still receive 16 percent less in benefits than non-mothers, and each additional child reduces benefits by another 2 percent.

- The per-child motherhood penalty is almost negligible among women receiving spousal benefits, but mothers who receive benefits on only their own earnings histories see significantly lower Social Security income than childless working women, and for each child.

The policy implications of the findings are:

- Mothers end up less well off in economic terms when spousal benefits are not available.

- With the receipt of spousal benefits likely to continue its decline, policymakers may want to consider whether to compensate women for their lost earnings due to motherhood. 


\section{Introduction}

Female labor force participation has increased markedly over the past couple of decades, as have the number of women who enter retirement single (Munnell et al. 2017), so many working women today will be claiming Social Security benefits earned on their own earnings histories. However, family situations that occur over the years still impact women's lifetime earnings and subsequently their retirement security. While women have shifted their focus to market production, they often still take on the majority of the child care responsibilities. Women's earnings take a substantial and long-lasting hit when they first become mothers and additional hits after having subsequent children, due to more time out of the work force, a higher cost of searching for a job, and poor job match quality (Mincer and Polachek 1974; Budig and England 2001; Lundberg and Rose 2002; Loughran and Zissimopoulos 2009; Herr 2016).

If motherhood lowers earnings, and these losses are not made up later, then having children could give rise to a career's worth of lower annual earnings, which would result in significantly smaller Social Security checks. But most of the literature has tended to focus on reductions in women's earnings only in the years in which their children are young. ${ }^{1}$ As a result, the extent to which motherhood is associated with lower earnings throughout their entire working lives is not well understood. Furthermore, even if mothers' lifetime earnings are much lower, Social Security benefits may not be, as the system compensates any person who has lower earnings with a progressive benefit formula that lets them keep a higher share of their earnings the less that they earn. The Social Security system also makes spousal benefits available for those who were married for 10 years or more. To fill this gap in the literature, this paper studies the relationship between motherhood, lifetime earnings, and Social Security benefits.

This paper uses data from the Health and Retirement Study linked to the U.S. Social Security Administration (SSA) earnings records to measure the association between lifetime earnings and motherhood among women born between 1931 and 1959. The study also analyzes the ultimate difference in Social Security income at age 62 (when benefits are first available) between non-mothers and mothers, and also among mothers grouped by their number of children, to determine the extent to which the Social Security system - through spousal benefits and progressivity - decreases the motherhood penalty.

\footnotetext{
${ }^{1}$ Miller (2013) and Kahn et al. (2014) also study women’s contemporaneous earnings in mid- to late life.
} 
The results indicate that, all else equal, mothers with one child have 28 percent lower lifetime earnings than non-mothers, and each additional child is associated with 3 percent lower earnings. For example, a woman with two children would earn 31 percent less over her career than a childless woman. The differences in Social Security benefits are smaller than the gap in career earnings, however: 16 percent less goes to mothers with one child compared to nonmothers, plus about 2 percent for each additional child. However, the results of a comparison among women without spousal benefits shows that the mothers receive significantly lower Social Security benefits.

The paper proceeds as follows. The next section reviews the literature on the labor market effects of motherhood. The third section describes the HRS data, the SSA's earnings records, and the econometric strategy used in this study. The fourth section provides the results. The final section concludes that the Social Security system reduces the motherhood earnings penalty but still leaves women who receive only their own benefits worse off, and that the decline of spousal benefits may justify efforts to compensate mothers for their earnings losses.

\section{Background}

While the Social Security system does not explicitly compensate caregivers for time spent out of the labor force, the program has two features that can lessen the reduction in benefits due to mothers' lost earnings: 1) the spousal benefit; and 2) the progressive benefit formula. The Social Security spousal benefit, introduced in 1939, allows people who were married at least 10 years to claim benefits on their spouse's (or ex-spouse's) record equal to one-half of the Primary Insurance Amount (PIA) of the higher-earning spouse, usually the husband. ${ }^{2}$ If the spousal benefit is claimed before the lower-earning spouse reaches her Full Retirement Age, her benefit is reduced. If the individual is eligible for Social Security benefits on her own earnings record, she will receive the higher of the two benefits. In that case, that individual is considered to be “dually entitled,” receiving the benefits earned based on her own work history and being “topped up” so that her benefit reaches 50 percent of her spouse’s benefits.

\footnotetext{
2 The first step in calculating a worker's PIA is the Average Indexed Monthly Earnings (AIME). The AIME is calculated as the average of the 35 highest years of annual earnings, adjusted for wage inflation (and divided by 12 to present a monthly amount). If a worker has worked fewer than 35 years, the remaining years are set to zero. Replacing a zero in one's work history can therefore increase the PIA substantially (Rutledge and Lindner 2016). The AIME is then converted into the PIA using a progressive formula, which assures that low earners' benefits represent a greater share of their earnings. Finally, benefits are reduced for claiming before the Full Retirement Age (FRA), or increased for claiming thereafter.
} 
Increasingly, however, women are receiving Social Security benefits solely based on their own earnings records, rather than receiving spousal benefits. In the last several decades, female labor force participation has increased remarkably, as has the share of women reaching retirement without having been married for at least 10 years (Wu et al. 2013). These changes mean women are less likely to receive spousal benefits today. The fact that their earnings are lower due to having children could be mitigated somewhat by the progressivity of the program's benefit formula, though probably to a lesser extent than the spousal benefit.

The trend away from spousal benefits makes obtaining an accurate measure of the effects of motherhood on lifetime earnings ever more important. It has been well established that women's earnings decrease when they become mothers (e.g. Korenman and Neumark 1992; Waldfogel 1997; Budig and England 2002; Avellar and Smock 2003). ${ }^{3}$ Overall, the motherhood earnings penalty has been related to less educational attainment, more time out of the work force, a higher cost of searching for a job, and poor job match quality (Budig and England 2001; Lundberg and Rose 2002; Wilde, Batchelder, and Ellwood 2010; Miller 2011; Miller 2013; Herr 2016). However, most of these studies have focused on earnings during women's childbearing and child-rearing years, while relatively few have studied their earnings in mid- to late career. An exception is Kahn et al. (2014), which finds that that while most mothers are able to close the earnings gap by the time they reach their 40s and 50s, those with more than three children do not.

Of course, the number of children is also an important determinant of the motherhood earnings gap. Most studies find that after the initial penalty for becoming a mother, each additional child reduces earnings further (Korenman and Neumark 1992; Waldfogel 1997; Budig and England 2001; Wilde, Batchelder, and Ellwood 2010; Kahn 2014). ${ }^{4}$ Recent generations of mothers have had fewer children (Mathews and Hamilton 2002; Mathews and Hamilton 2016), so they may experience less of an impact on their career earnings. The literature also indicates that the timing of birth matters - compared to women who delay motherhood, younger mothers have lower contemporaneous earnings due to lower educational attainment, less on-the-job experience (prior to childbearing), and higher transaction costs from the job search (Miller 2011; Miller 2013; Wild, Batchelder, and Ellwood 2010). Because women from later cohorts have

\footnotetext{
${ }^{3}$ Some studies find that motherhood also affects wage growth (Miller 2011; Wilde, Batchelder, and Ellwood 2010), while others do not (Korenman and Neumark 1992; Loughran and Zissimopolous 2009).

${ }^{4}$ Loughran and Zissimopolous (2009), however, do not find further wage reduction with subsequent children.
} 
children at older ages, some specifications of the analysis discussed below incorporate the timing of the woman's first birth.

\section{Data and Methodology}

The analysis uses the 1992-2014 waves of the Health and Retirement Study (HRS), a longitudinal dataset that surveys people ages 50 or older every two years about their labor market outcomes, public benefit receipt, family structure, and other relevant characteristics. The publicuse HRS is linked to SSA's administrative earnings records to provide accurate information on mothers’ earnings histories and potential Social Security income.

The sample includes women born in 1931-1959. The sample is limited to women who were childless or who had biological children; women who were stepmothers without their own biological children, or whose relationships with their children were all unknown, are excluded. The sample also excludes women who were married for 10 or more years but divorced before entering the HRS, because their spousal benefits (and, therefore, their final Social Security income) are unknown. The sample also excludes widows, whose Social Security benefits are usually unrelated to their own earnings. ${ }^{5}$ Finally, the sample excludes any women who report receiving Social Security Disability Insurance at any point or Supplemental Security Income before age 62; receipt of either disability benefit indicates mothers had an early end to their careers for health reasons, which may not be connected to their fertility history.

The first outcome of interest is a woman's lifetime earnings as measured by her Average Indexed Monthly Earnings (AIME) - how much she earned (wages earned below age 60 are indexed to the average wages in the year she turned 60) in the average month. The AIME is calculated for her top 35 years of real earnings using data from the Social Security summary earnings records, which report her annual earnings in each year from 1951-2013. Because the birth cohorts range so widely, including years of earnings at age 62 or later would exaggerate the

\footnotetext{
${ }^{5}$ Other outliers are also removed, including women whose first births were over age 35 or under 15 , and those who report having more than 17 children. The sample also excludes any respondent who enters the HRS at age 63 or older. Women who entered the sample in 2014 were also excluded because the RAND family files are updated only through 2012, and women whose reports of births are inconsistent between the RAND core and family files are also dropped.
} 
differences between older and younger cohorts. To ameliorate this bias, the study calculates the AIME using earnings up through age 61 , or her last year in the survey. ${ }^{6}$

A second outcome of interest is the Social Security income a woman can draw from her or her spouse's earnings histories. Limiting the AIME calculation through age 61 implicitly assumes that each woman claims at 62; the analysis accounts for the actuarial adjustment she would face by claiming at that age. Although Social Security benefits are calculated using the AIME, the benefit level itself is still of interest for two reasons. First, a large - but declining share of women in these cohorts receive spousal benefits, eliminating the reliance of their benefit on their own earnings' history. ${ }^{7}$ Second, for women who do rely on their own Social Security benefits, the formula is progressive, shrinking the difference in retirement income between highand low-earners over their careers. The analysis using Social Security income assigns the woman the maximum of the benefit she would get based on either her spouse's earnings history or her own earnings history.

To better ensure that differences among women in lifetime earnings and Social Security income are not simply the result of differences in their personal characteristics, the project estimates linear regression models that control for their observable differences. The sample includes one observation per mother, where the dependent variable is her AIME or Social Security benefit earned by the end of her time in the sample. ${ }^{8}$

The key independent variables in the regressions are two measures of fertility: 1) whether the woman is a mother; and 2) her total number of children. These variables are constructed using the RAND HRS family files, which report each child's birth year and relationship to the

\footnotetext{
${ }^{6}$ Because some women, especially in more recent cohorts, do not reach age 61 in the earnings file, the AIME - and the corresponding potential Social Security benefit - are prorated. Rather than average over 35 years of earnings, the average is taken over her maximum age minus 26 years, up to 35 years; for example, a woman who only reaches age 55 in the earnings file will have her AIME calculated over her top $55-26=29$ years, so as to not penalize her for years of earnings she has not had the opportunity to accumulate.

${ }^{7}$ Technically, spousal benefits top off any benefit the lower-earning spouse accumulates on her own record, but either way she ends up with the greater of her own benefit or one-half of her spouse's Primary Insurance Amount. Her benefit is not based on when he claimed his own benefit, but individuals can only receive spousal benefits if the primary earner has claimed his benefit. Some primary-earning husbands are younger, but the analysis aims to account for the spousal benefit the lower-earning wife would have accrued, so it assumes that the spousal benefit is nonetheless available to her when she reaches age 62.

${ }^{8}$ Each regression is also estimated using the natural logarithm of AIME or the Social Security benefit. The results are similar in sign and statistical significance, though the magnitudes are larger than previous estimates of the motherhood earnings penalty. These results are available upon request.
} 
HRS respondent. ${ }^{9}$ The findings in the literature suggest that the signs on the motherhood and number of children coefficients are negative: mothers earn less than non-mothers, and each additional child is associated with further earnings declines. In all cases, the coefficient in the Social Security benefit regressions are expected to be smaller, in part because Social Security replacement rates are less than one. But the decrease in magnitude between the earnings and Social Security regressions also reflects the extent to which the Social Security system - through spousal benefits and progressivity - reduces the motherhood penalty.

One important aspect worth extended discussion is a woman's own education, which is included as a control even though educational attainment is also a pathway through which motherhood may affect lifetime earnings. By controlling for the woman's education, the coefficient on any of the fertility variables would not reflect that a mother may have received less education because of when and how often she had children. This endogeneity would suggest a woman's own education should not be included. However, education is an important proxy for job prospects and other measures of personal stability; therefore, the analysis presents the results with the woman's own education. ${ }^{10}$

The regression models also control for other characteristics directly related to career earnings. As discussed above, the literature has established that a mother's age at the time of her first child's birth affects contemporaneous earnings, and more recent generations of women have delayed their first births; therefore, the study estimates a separate model among mothers that includes a control for the age at first birth. The controls also include race (black vs. Hispanic/other race, with white as the omitted category); marital status at either age 62 or her last year in the survey (never married vs. separated/divorced, with currently married as the omitted

\footnotetext{
${ }^{9}$ The child's relationship status is either the respondent's own biological child, stepchild, or a child of indeterminate status. Stepchildren are excluded because the stepmother likely did not reduce her labor force participation when that child was born. Children of indeterminate status are included if their personal information (such as gender and birth year) and relationship status with the respondent throughout their time in the sample was consistent. If some of these children are not biological children in reality, including them understates the difference between mothers with a small number of children and mothers with a larger number of children. Therefore, the results shown in this paper are, if anything, understating the true relationship between the number of children and lifetime earnings or Social Security benefits.

${ }^{10}$ Results without the education control are available upon request, but are qualitatively similar. Each regression was also estimated with an alternative control for education: an indicator for whether the woman attained more education than her parents (whichever parent was better educated). This variable can be seen as a proxy for own education: it is more likely to be true if she gets more education, but is not so directly tied to her fertility experience, so it may be less endogenous than controlling for her own education directly. The estimates in the specifications that used this proxy had coefficients that were usually halfway in between the no-education and with-education specifications and are also available on request.
} 
category); an indicator for having ever reported a work-limiting health condition; an indicator for having resident children when the woman is age 62 (or her last year in the survey); and categorical indicators for the woman's birth cohort. The controls also include variables intended to account for the woman's socioeconomic background, which may affect her fertility history, including indicators for whether she grew up in a rural environment, whether she reports that religion is important to her, and categorical variables for her mother's education.

Even more generally than the endogeneity of education's relationship with motherhood, the endogeneity of motherhood itself is a concern in interpreting the results. For example, if women with lower earnings prospects are more likely to become mothers and tend to have larger families, but those earnings prospects are not properly accounted for, the current regression analysis would overstate motherhood's negative effect on lifetime earnings. The results in this paper, therefore, should be interpreted as the association between motherhood and lifetime earnings or Social Security benefits. A causal estimate is necessary to determine the true motherhood penalty, but since little is known about these associations in the existing literature, providing information about them contributes to the research and policy community's understanding of mothers’ long-run well-being.

\section{Results}

This section first presents the raw differences in AIME and Social Security benefits without adjusting (as in the regression) for differences between mothers and non-mothers overall and by cohort, and then presents the regression results.

\section{Unadjusted Differences in Lifetime Earnings and Social Security Benefits}

Table 1 shows that the median AIME is substantially lower for mothers compared to nonmothers, and that it is lower the more children she has. Non-mothers in the HRS sample have a median AIME of nearly \$3,900 per month, while mothers' median AIME is about \$1,400 (60 percent less); this difference should be interpreted with caution, since non-mothers account for only 7 percent of the sample. The differences based on their number of children are also large: mothers with two children earn 30 percent less in their average month than women with one child, and women with three or more children earn almost 60 percent less. 
The right column of Table 1 shows that the progressive nature of Social Security benefits and the availability of spousal benefits help reduce the gaps between women with and without children, and between mothers with smaller and larger families. Even though the median mother earns 63 percent less than childless women, her Social Security benefit is only 40 percent lower. Similarly, compared to women with one child, median Social Security benefits are only 13 percent lower for women with two children, and 26 percent lower for women with three or more children, compared to respective differences of 30 percent and 59 percent in AIME.

\section{Differences in Earnings and Social Security Benefits across Birth Cohorts}

Figure 1 shows that the motherhood earnings penalty, relative to non-mothers, appears to be large but consistent across cohorts. Among mothers, the gap between women with one or two children and those with three or more has also remained about the same. Consistent with Table 1, Figure 2 shows smaller differences in Social Security benefits by fertility outcomes across cohorts than in AIME. The difference between women with and without children is also roughly constant over time.

\section{Regression Estimates of Motherhood on Career Earnings and Social Security Benefits}

Table 2 shows the estimates from the regression of AIME (first two columns) and Social Security benefits (latter two columns) on the motherhood variables and other personal characteristics among all women. The results in the first and third columns only include a motherhood indicator, while the second and fourth columns also include a control for the number of children. Full results are available in Appendix Table A1.

The results in the first column of Table 2 confirm the earlier unadjusted evidence that, even after controlling for differences between mothers and childless women, motherhood is associated with substantially lower lifetime earnings. Mothers' lifetime earnings are $\$ 1,278$ less per month than the earnings of childless women - or 33 percent of the childless women's median earnings of $\$ 3,850$ (Table 1). The second column includes a control for the number of children, so the relevant comparison is between a non-mother and a mother with one child. That comparison requires adding together the first two coefficients; the sum indicates that mothers 
with one child earn \$1,090 less, or 28 percent of the non-mothers’ median earnings. ${ }^{11}$ The results indicate that the earnings loss associated with having the first child (and simply becoming a mother) is much larger than any subsequent child; those later children each reduce the AIME further by $\$ 132$, or 3.4 percent of the non-mothers' median. ${ }^{12}$ This estimate for the additional per-child reduction is in line with the prior literature on the effects of children on earnings at specific points in a woman's career. ${ }^{13}$

The right two columns of Table 2 indicate that the results are qualitatively similar for Social Security benefits, though smaller in magnitude - being a mother and having a greater number of children are both associated with lower benefits. The smaller difference between nonmothers and mothers is due in part to spousal benefits and in part to the progressive nature of Social Security benefits. Relative to non-mothers, mothers receive \$250 less per month from Social Security (19 percent of the median benefits for childless women, \$1,301 in Table 1) in models that do not control for the number of children. The sum of the first two coefficients in the fourth column indicates that mothers with just one child receive $\$ 209$, or 16 percent less than non-mothers. Each additional child is associated with monthly benefits that are \$29 lower, or 2.2 percent of non-mothers' median benefits. All of these estimates are statistically significant, but the magnitudes are markedly smaller than the AIME estimates in Table 2.

The dollar estimates of the effect of motherhood on Social Security income are smaller than the AIME estimates, in part, because Social Security's replacement rate is less than 100 percent. Beyond that, progressivity and spousal benefits reduce the absolute level of the

\footnotetext{
11 The estimated 28-percent gap between non-mothers and mothers with one child is somewhat large compared to the literature, even though they are in line with findings of significantly slower wage growth among high achieving mothers (Wilde, Batchelder, and Ellwood 2010). But our large estimate could be due to the small sample size of non-mothers.

12 Other estimates in the regressions largely fit expectations. Women of Hispanic origin, those who have had previous health limitations, those who lived in rural areas, and those who find religion very important have lower lifetime earnings. Divorced women earn substantially more than women who are continuously married, as found in previous studies (e.g., Tamborini, Couch, and Reznik 2015). Among mothers, black women have higher lifetime earnings than white women, which is in line findings that labor force participation rates are higher for black women with children under 18 (BLS 2007).

${ }^{13}$ Korenman and Neumark (1992) find that, after controlling for education, wages are 4-5 percent lower for mothers with one child, and 7-18 percent lower for mothers with two or more children. Waldfogel (1997) finds that one child lowers wages by 1.8-6.4 percent, and two or more children lowers wages by 2-11 percent. Wilde, Batchelder, and Ellwood (2010) find 2-7 percent lower wages for each child after the first. Herr (2016) estimates per-child effects ranging from 1-6 percent. Kahn (2014) finds that women with 3 or more children earn 4 percent less per child in their 50s. Our estimates are reported as a percentage of the median for non-mothers, but could instead be evaluated relative to the median of mothers with just one child; in that case, the per-child earning penalty of additional children is 5.3 percent instead of 3.4 percent.
} 
motherhood penalty further. The ratio of the estimates (relative to median AIME and Social Security benefits) is a way to account for how the Social Security system reduces the motherhood penalty. The results suggest the gap between non-mothers' and mothers' AIMEs is 33 percent of the non-mothers' median, while the gap is only 19 percent for Social Security benefits, a reduction of 42 percent. Results are similar when comparing the reduction in the difference between childless women and mothers with one child (43 percent). The per-child penalty is reduced from 3.4 percent to 2.2 percent, or by 36 percent. $^{14}$

\section{Regression Results for Mothers Only}

Table 3 presents separate estimates from the subsample of women who have had children. These estimates are separated for two reasons. First, the sample of non-mothers is small - especially among spousal beneficiaries (shown separately in Table 4) - so presenting separate results checks whether this group adds noise to the main estimates. Second, limiting the sample to mothers allows for more easily controlling for the woman's age at first birth, which is shown in the second and fourth columns.

The first two columns of Table 3 show a similar per-child earnings penalty (\$154-\$159) to the one estimated for earnings in Table $2(\$ 132)^{15}$ The per-child Social Security benefit reduction in the third and fourth columns $(\$ 32-\$ 34)$ is also similar to the estimate in Table 2 (\$29). This indicates that the results are not altered by having a small group of non-mothers and by the non-linearity apparent in the difference between having one's first child and having one's second child. Furthermore, the results are similar when controlling for the age at first birth, which itself has only a small and statistically insignificant relationship with AIME and Social Security benefits (in large part because the model controls for education). ${ }^{16}$

\footnotetext{
${ }^{14}$ The regression results are similar by cohort. The by-cohort estimates of the per-child earnings penalty increase slightly, from 2.1 percent of the mothers' median AIME for the 1931-1933 cohort to 8.5 percent for the 1946-1949 cohort, but the results are only barely statistically significant, and some later sample sizes are quite small. The trend is also toward larger losses, but by an even less statistically significant amount, for the per-child loss in Social Security benefits.

${ }^{15}$ Full results for the regressions in Table 3 are presented in Appendix Table A2.

${ }^{16}$ The coefficient on age at first birth is larger and statistically significant when education is not included (\$25, or 2 percent of mothers' median AIME), in line with prior work that indicates that having children early in life hinders earnings through lower educational attainment (Miller 2013).
} 


\section{Results by Type of Social Security Benefit}

The above results suggest that women face an earnings penalty for becoming a mother and having additional children and that the Social Security system reduces this penalty by about 40 percent. The results in Table 4 split the sample between those receiving only their own benefits (first two columns) and those receiving spousal benefits (third column). These results indicate that spousal benefits essentially close the per-child gap in Social Security benefits. On the other hand, while the group receiving their own benefits are helped by the progressive benefit formula, mothers do fare worse.

The first column of the top panel of Table 4 shows that, all else equal, mothers who do not receive spousal benefits have earnings that are $\$ 1,026$ lower, or 27 percent less, than nonmothers' median earnings. In the bottom panel, their Social Security benefits are only $\$ 222$, or 17 percent, less than non-mothers, a reduction in the motherhood penalty of 36 percent. Because this group does not receive spousal benefits, these reductions are due entirely to the progressivity of the benefit formula. ${ }^{17}$

The remainder of Table 4 shows results comparing only mothers, because only about 40 women in the spousal beneficiary group are non-mothers. Among mothers with no spousal benefits, earnings are \$132 lower per child, or 3.4 percent of mothers' median earnings. Their Social Security benefits are $\$ 37$ lower, or 2.8 percent of the median, which means that progressivity reduces the per-child penalty by only 17 percent for mothers who do not get spousal benefits.

Spousal beneficiaries, on the other hand, have a much smaller per-child loss of AIME: only $\$ 22$, or 0.6 percent of the median AIME, though it is still statistically significant. The smaller association between motherhood and earnings among spousal beneficiaries could indicate that these women spent large portions of their prime ages not working, in most cases as stay-at-home mothers. Their per-child difference in Social Security benefits is even smaller: only $\$ 4$ per month, or 0.3 percent of non-mothers’ median benefits. The per-child penalty relative to the non-mother's median, therefore, falls by 44 percent. This result is entirely due to

\footnotetext{
${ }^{17}$ The results are similar when splitting the group not receiving spousal benefits into: a) those who were never married for at least ten years, so they were not eligible for spousal benefits; and $b$ ) were married for ten or more years so that they were eligible for spousal benefits, but who received a greater benefit from their own record. We also split the latter group between those who were continuously married vs. those who divorced after ten years of marriage, and the per-child earnings penalty - and the Social Security system's reduction of that penalty - were very similar.
} 
spousal benefits, because their benefit does not depend on applying the progressive benefit formula to their own earnings. ${ }^{18}$ Women receiving spousal benefits, therefore, have only a small per-child penalty. However, with spousal benefits in decline - 46 percent receive them in the 1931-1933 cohort but only 24 percent in the 1954-1959 cohort - this aspect of the Social Security system will do less to reduce the motherhood penalty going forward.

\section{Conclusion}

The results from this study suggest that motherhood substantially reduces lifetime earnings, compared with non-mothers, and that having more children is associated with even larger reductions. The prior literature indicates that mothers earn less while raising children; the contribution of this study to that literature is the finding that mothers are not able to make up for this earnings penalty by the time that they become eligible for Social Security benefits. At that point, however, the Social Security system ensures that mothers do not face a gap in retirement income fully commensurate with their lower earnings. The gaps between the Social Security benefits received by mothers and non-mothers, or between women with different numbers of children, while still considerable, are about 40 percent smaller than the gaps in their earnings. Among spousal beneficiaries, the difference in Social Security benefits when comparing mothers by their number of children is very small, which indicates that spousal benefits play an important role in reducing the gap. But the decreasing share of women receiving spousal benefits means that, if mothers continue to earn lower wages over their careers, they will see even lower Social Security income going forward.

These estimates are subject to some caveats. Due to the existence of younger birth cohorts in the study sample, the current results have focused on how AIMEs differ up to age 62, but mothers may compensate for lost earnings by extending their careers. Prior studies have found evidence that mothers with more children retire later (Pienta 1999; Chung 2010), and the current estimates may overstate the ultimate differences in Social Security benefits between mothers with many versus few children. The current results also cannot be interpreted as the causal effects of motherhood because of concerns about the endogeneity of motherhood.

\footnotetext{
${ }^{18}$ The analysis also examined the per-child penalty in the benefits that spousal beneficiaries would get just based on their own records - that is, ignoring spousal benefits. The absolute difference in Social Security benefits for having an additional child (\$13) is smaller than the absolute per-child earnings penalty (\$21), but the per-child penalty as a share of the medians is almost exactly equal. This result indicates that progressivity does not help this group - as expected, because their Social Security benefits are not dependent on their own earnings records.
} 
Even given these caveats, the results provide information on how much less mothers earn over their careers than non-mothers, and how the Social Security system, as currently constituted, reduces this disparity. These results contribute to the ongoing discussion about whether, or how, to compensate mothers for foregone earnings, especially as spousal benefits continue to decline in importance. The U.S. House and Senate have introduced matching legislation - the Social Security Caregiver Credit Act - that would give mothers (and other caregivers, regardless of gender) credit for lost earnings when calculating retirement benefits. While the Act may have other goals as well - such as the promotion of fertility and caregiving (Jankowski 2011) - its primary objective is improving retirement benefit adequacy. The results suggest that while Social Security already reduces the motherhood penalty by about 40 percent, a sizeable difference in benefits remains, which policymakers may want to consider closing further. 


\section{References}

Avellar, Sarah, and Pamela Smock. 2003. "Has the Price of Motherhood Declined Over Time? A Cross-Cohort Comparison of the Motherhood Wage Penalty.” Journal of Marriage and Family 65(3): 597-607.

Budig, Michelle J. and Paula England. 2001. “The Wage Penalty for Motherhood.” American Sociological Review 66: 204-225.

Chung, Hsiao-Yin. 2010. “The Effects of Childbearing Patterns on the Timing of Retirement.” Doctoral Dissertation. University of Massachusetts, Boston.

Herr, Jane Leber. 2016. “Measuring the Effect of the Timing of First Birth.” Journal of Population Economics 29(1): 39-72.

Jankowski, John. 2011. "Caregiver Credits in France, Germany, and Sweden: Lessons for the United States.” Social Security Bulletin 71(4): 61-76.

Kahn, Joan R., Javier García-Manglano, and Suzanne M. Bianchi. 2014. "The Motherhood Penalty at Midlife: Long-Term Effects of Children on Women's Careers.” Journal of Marriage and the Family 76(1): 56-72.

Korenman, Sanders and David Neumark. 1992. “Marriage, Motherhood, and Wages.” Journal of Human Resources 27(2): 233-255

Loughran, David S., and Julie Zissimopoulos. 2009. "Why Wait? The Effect of Marriage and Childbearing on the Wage Growth of Men and Women.” Journal of Human Resources 44: 326-349

Lundberg, Shelly and Elaina Rose. 2002. "The Effects of Sons and Daughters on Men's Labor Supply and Wages.” Review of Economics and Statistics 84(2): 251-268.

Mathews T.J. and Brady E. Hamilton. 2002. Mean Age of Mother, 1970-2000. National Vital Statistics Reports 51(1). Hyattsville, MD: National Center for Health Statistics.

. 2016. Mean Age of Mothers Is on the Rise: United States, 2000-2014. Data Brief 232. Hyattsville, MD: National Center for Health Statistics.

Miller, Amalia. 2011. “The Effects of Motherhood Timing on Career Path.” Journal of Population Economics 24(3): 1071-1100.

Miller, Amalia R. 2013. “Marriage Timing, Motherhood Timing and Women’s Wellbeing in Retirement.” In Lifecycle Events and Their Consequences: Job Loss, Family Change, and Declines in Health, edited by Kenneth A. Couch, Mary C. Daly, and Julie Zissimopoulos, 109-132. Stanford, CA: Stanford University Press. 
Mincer, Jacob and Solomon Polachek. 1974. "Family Investments in Human Capital: Earnings of Women.” Journal of Political Economy 82(2): S76-S108.

Munnell, Alicia H., Geoffrey T. Sanzenbacher, and Sara Ellen King. 2017. "Do Women Still Spend Most of Their Lives Married?” Issue in Brief 17-14. Chestnut Hill, MA: Center for Retirement Research at Boston College.

Pienta, Amy. 1999. "Early Childbearing Patterns and Women's Labor Force Behavior in Later Life.” Journal of Women and Aging 11(1): 69-84.

Rutledge, Matthew S. and John E. Lindner. 2016. "Do Late-Career Wages Boost Social Security More for Women than Men?” Working Paper 2016-13. Chestnut Hill, MA: Center for Retirement Research at Boston College.

Tamborini, Christopher R., Kenneth A. Couch, and Gayle L. Reznik. 2015. "Long-term Impact of Divorce on Women's Earnings across Multiple Divorce Windows: A Life Course Perspective.” Advances in life Course Research 26(4): 44-59.

U.S. Bureau of Labor Statistics. 2007. Labor Force Characteristics by Race and Ethnicity. Report No. 1005. Washington, DC.

Waldfogel, Jane. 1997. “The Effect of Children on Women's Wages.” American Sociological Review 62(2): 209-217.

Wilde, Elizabeth Ty, Lily Batchelder, and David T. Ellwood. 2010. “The Mommy Track Divides: The Impact of Childbearing on Wages of Women of Differing Skill Levels." Working Paper 16582. Cambridge, MA: National Bureau of Economic Research.

Wu, April Yanyuan, Nadia S. Karamcheva, Alicia H. Munnell, and Patrick Purcell. 2013. "How Do the Changing Labor Supply Behavior and Marriage Patterns of Women Affect Social Security Replacement Rates?” Working Paper 2013-16. Chestnut Hill, MA: Center for Retirement Research at Boston College. 
Figure 1. Median AIME by Number of Children and Birth Cohort

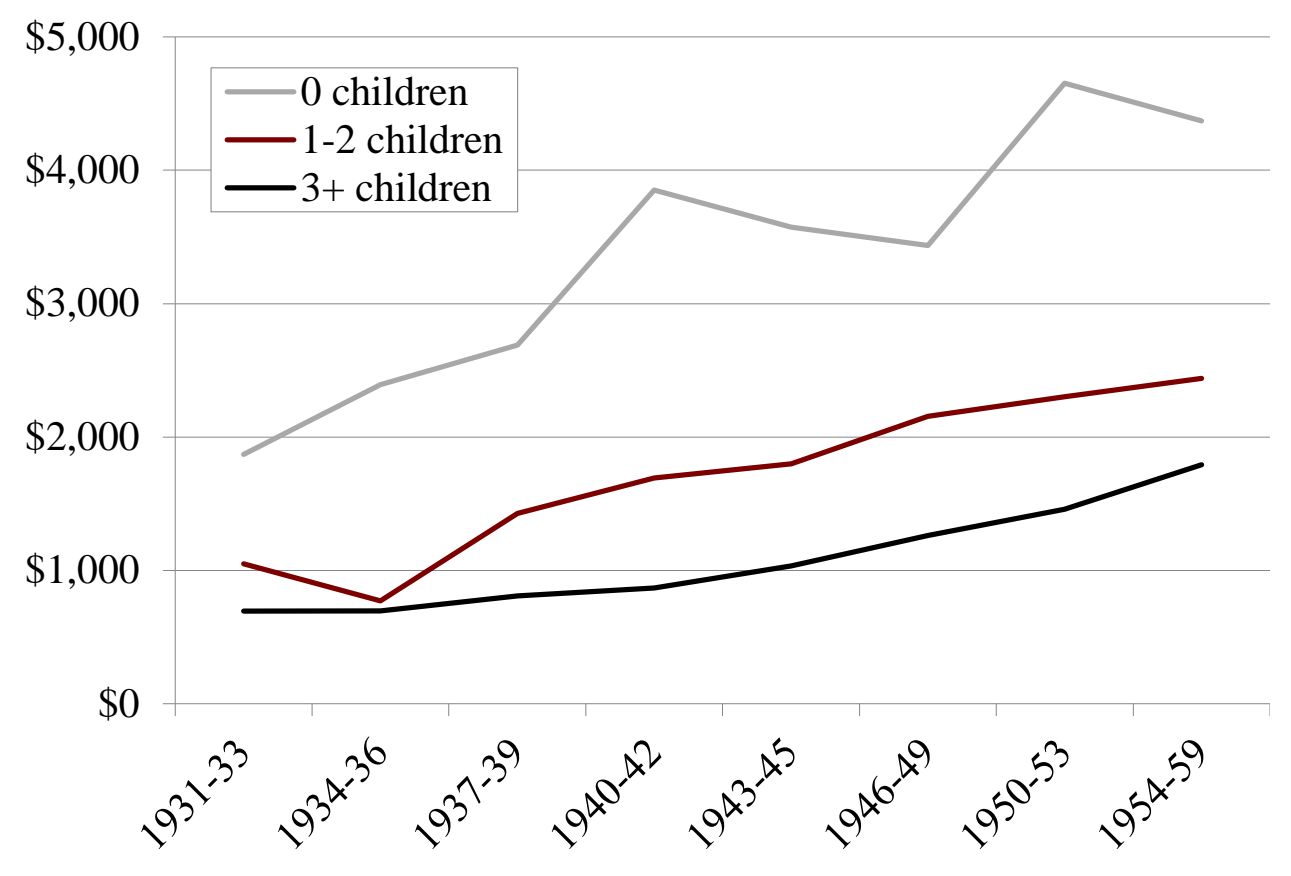

Source: Health and Retirement Study, 1992-2014.

Figure 2. Median Social Security Benefits by Number of Children and Birth Cohort

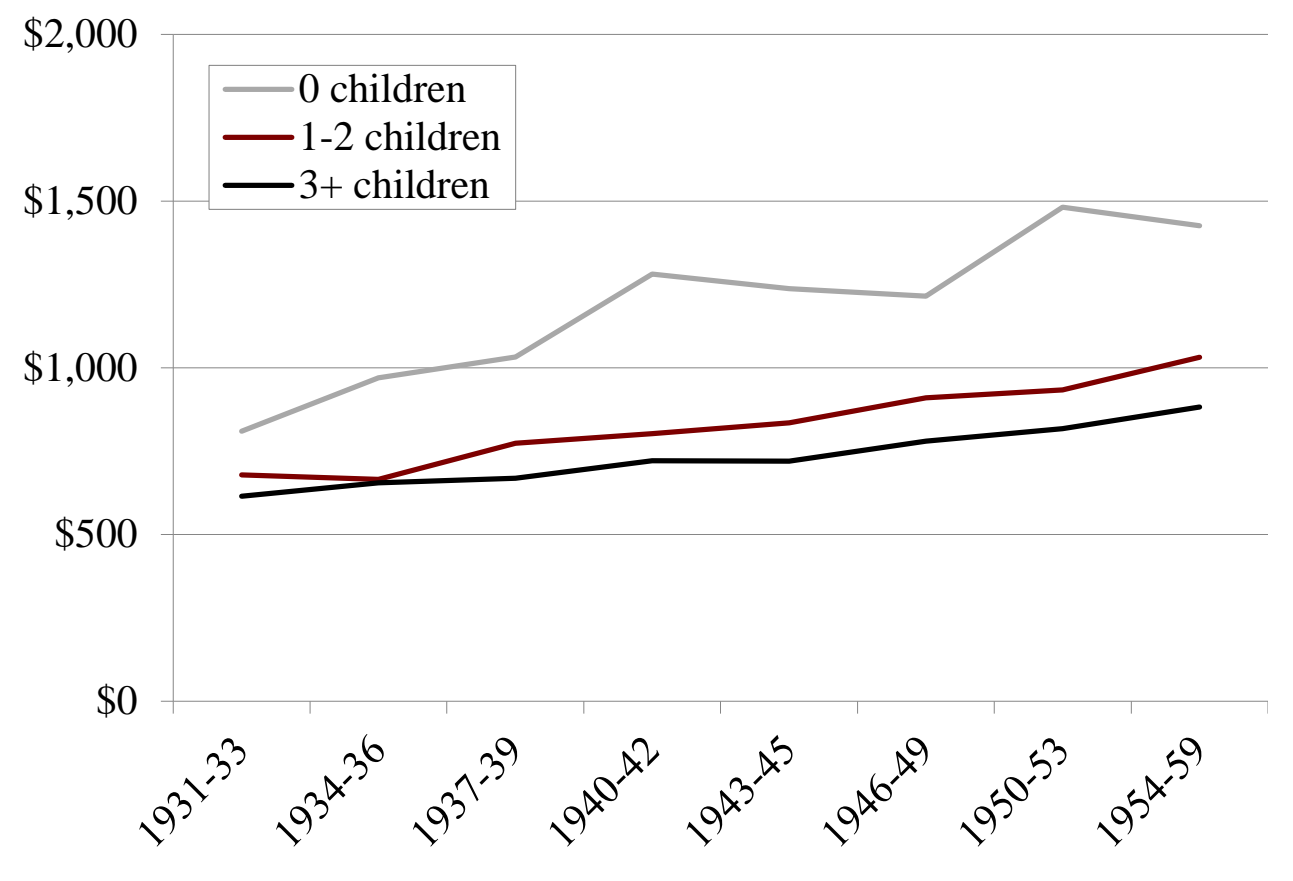

Source: Health and Retirement Study, 1992-2014 
Table 1. Women's Median AIME and Social Security Benefits, by Number of Children

\begin{tabular}{lcccc}
\hline & \multicolumn{2}{c}{ AIME } & \multicolumn{2}{c}{ Social Security benefit } \\
\cline { 2 - 5 } Mother status & $\begin{array}{c}\text { Median } \\
\text { (per month) }\end{array}$ & $\begin{array}{c}\text { \% difference from } \\
\text { non-mothers }\end{array}$ & $\begin{array}{c}\text { Median } \\
\text { (per month) }\end{array}$ & $\begin{array}{c}\text { \% difference from } \\
\text { non-mothers }\end{array}$ \\
\hline Non-mothers & $\$ 3,850$ & & $\$ 1,301$ & \\
\multicolumn{1}{c}{ Mothers } & 1,409 & $-63.4 \%$ & 785 & $-39.6 \%$ \\
\hline Number of children & Median & \% difference from & Median & \% difference from \\
(mothers only) & (per month) & mothers with 1 kid & (per month) & mothers with 1 kid \\
\hline 1 kid & $\$ 2,498$ & & $\$ 974$ & \\
2 kids & 1,759 & $-29.6 \%$ & 847 & $-13.0 \%$ \\
3+ kids & 1,027 & -58.9 & 717 & -26.4 \\
\hline
\end{tabular}

Notes: Medians are in 2014 dollars.

Source: Health and Retirement Study, 1992-2014.

Table 2. Linear Regression Estimates of Career Earnings and Social Security Benefits on Motherhood and Number of Children

\begin{tabular}{|c|c|c|c|c|}
\hline \multirow[b]{2}{*}{ Dependent variable } & \multicolumn{2}{|c|}{ AIME } & \multicolumn{2}{|c|}{ Social Security benefit } \\
\hline & $(1)$ & $(2)$ & (3) & (4) \\
\hline \multirow[t]{2}{*}{ Mother (0/1) } & $-1,278 * * *$ & $-958 * * *$ & $-250 * * *$ & $-180 * * *$ \\
\hline & $(161)$ & $(166)$ & $(34)$ & (35) \\
\hline$\%$ of non-mothers' median & $33 \%$ & $25 \%$ & $19 \%$ & $14 \%$ \\
\hline \multirow[t]{2}{*}{ Number of children } & & $-132 * * *$ & & $-29 * * *$ \\
\hline & & $(16)$ & & (4) \\
\hline$\%$ of non-mothers' median & & $3.4 \%$ & & $2.2 \%$ \\
\hline \multirow[t]{2}{*}{ Own years of education } & $161^{* * *}$ & $148 * * *$ & $38 * * *$ & $35^{* * *}$ \\
\hline & $(14)$ & $(14)$ & (3) & (3) \\
\hline Observations & 4,171 & 4,171 & 4,171 & 4,171 \\
\hline $\mathrm{R}^{2}$ & 0.36 & 0.369 & 0.358 & 0.368 \\
\hline
\end{tabular}

Notes: AIMEs are in 2014 dollars. Each model also includes mother's education; race and Hispanic ethnicity; marital status; indicators for having a resident child at 62, growing up in a rural area, religiosity, and ever reporting a work-limiting health condition; and birth cohort dummies. Robust standard errors in parentheses. $\quad * * * \mathrm{p}<0.01, * *$ $\mathrm{p}<0.05,{ }^{*} \mathrm{p}<0.1$.

Source: Health and Retirement Study, 1992-2014. 
Table 3. Linear Regression Estimates of Career Earnings and Social Security Benefits on Number of Children, Mothers Only

\begin{tabular}{lcccc}
\hline \multirow{2}{*}{ Dependent variable } & \multicolumn{2}{c}{ AIME } & \multicolumn{2}{c}{ Social Security benefit } \\
\cline { 2 - 5 } Number of children & $(1)$ & $(2)$ & $(3)$ & $(4)$ \\
Age at first birth & $-159^{* * *}$ & $-154^{* * *}$ & $-34^{* * *}$ & $-32^{* * *}$ \\
& $(15)$ & $(16)$ & $(4)$ & $(4)$ \\
Own years of education & & 6 & & 2 \\
& & $(9)$ & & $(2)$ \\
\hline Observations & $123^{* * *}$ & $120^{* * *}$ & $31^{* * *}$ & $30^{* * *}$ \\
$\mathrm{R}^{2}$ & $(13)$ & $(14)$ & $(3)$ & $(3)$ \\
\hline
\end{tabular}

Notes: Social Security benefits are in 2014 dollars. Each model also includes mother's education; race and Hispanic ethnicity; marital status; indicators for growing up in a rural area, religiosity, and ever reporting a work-limiting health condition; and birth cohort dummies. Robust standard errors in parentheses. ${ }^{* * *} \mathrm{p}<0.01,{ }^{* *} \mathrm{p}<0.05,{ }^{*} \mathrm{p}<0.1$. Source: Health and Retirement Study, 1992-2014. 
Table 4. Linear Regression Estimates of AIME and Social Security Benefits on Motherhood, by Type of Social Security Benefit

\begin{tabular}{|c|c|c|c|}
\hline \multirow{3}{*}{$\begin{array}{l}\text { Dependent variable } \\
\text { (Sample) }\end{array}$} & \multicolumn{3}{|c|}{ AIME } \\
\hline & \multicolumn{2}{|c|}{ Do not receive spousal benefits } & \multirow{2}{*}{$\begin{array}{c}\text { Receive spousal benefits } \\
\text { Mothers only }\end{array}$} \\
\hline & All women & Mothers only & \\
\hline Mother (0/1) & $\begin{array}{l}-1,026^{* * *} \\
(157)\end{array}$ & --- & --- \\
\hline$\%$ of non-mothers' median & $27 \%$ & & \\
\hline $\begin{array}{l}\text { Number of children } \\
\qquad \% \text { of non-mothers' median }\end{array}$ & & $\begin{array}{l}-132 * * * \\
(23) \\
3.4 \%\end{array}$ & $\begin{array}{l}-22 * * * \\
(8) \\
0.6 \%\end{array}$ \\
\hline Observations & 2,574 & 2,262 & 1,560 \\
\hline \multirow[t]{2}{*}{$\mathrm{R}^{2}$} & 0.375 & 0.265 & 0.188 \\
\hline & \multicolumn{3}{|c|}{ Social Security benefit } \\
\hline \multirow{2}{*}{$\begin{array}{l}\text { Dependent variable } \\
\text { (Sample) }\end{array}$} & \multicolumn{2}{|c|}{ Do not receive spousal benefits } & Receive spousal benefits \\
\hline & All women & Mothers only & Mothers only \\
\hline Mother (0/1) & $\begin{array}{l}-222 * * * \\
(34)\end{array}$ & --- & --- \\
\hline$\%$ of non-mothers' median & $17 \%$ & & \\
\hline $\begin{array}{l}\text { Number of children } \\
\qquad \% \text { of non-mothers' median }\end{array}$ & & $\begin{array}{l}-37 * * * \\
(6) \\
2.8 \%\end{array}$ & $\begin{array}{l}-4 \\
(3) \\
0.3 \%\end{array}$ \\
\hline Observations & 2,574 & 2,262 & 1,560 \\
\hline $\mathrm{R}^{2}$ & 0.366 & 0.286 & 0.284 \\
\hline
\end{tabular}

Notes: AIMEs and Social Security benefits are in 2014 dollars. Each model includes same controls as prior regressions. Robust standard errors in parentheses. ${ }^{* * *} \mathrm{p}<0.01,{ }^{* *} \mathrm{p}<0.05,{ }^{*} \mathrm{p}<0.1$.

Source: Health and Retirement Study, 1992-2014. 


\section{Appendix}

Table A1. Linear Regression Estimates of AIME and Social Security Benefits on Motherhood and Number of Children, Detailed Results

\begin{tabular}{|c|c|c|c|c|}
\hline \multirow[t]{2}{*}{ Dependent variable } & \multicolumn{2}{|c|}{ AIME } & \multicolumn{2}{|c|}{ Social Security benefit } \\
\hline & $(1)$ & $(2)$ & (3) & (4) \\
\hline Mother (0/1) & $\begin{array}{c}-1,278 * * * \\
(161)\end{array}$ & $\begin{array}{l}-958 * * * \\
(166)\end{array}$ & $\begin{array}{l}-250 * * * \\
(34)\end{array}$ & $\begin{array}{l}-180 * * * \\
(35)\end{array}$ \\
\hline Number of children & & $\begin{array}{l}-132^{* * *} \\
(16)\end{array}$ & & $\begin{array}{l}-29 * * * \\
(4)\end{array}$ \\
\hline Young child living at home at age 62 & $\begin{array}{r}-107 \\
(266)\end{array}$ & $\begin{array}{r}197 \\
(267)\end{array}$ & $\begin{array}{l}-17 \\
(55)\end{array}$ & $\begin{array}{r}49 \\
(56)\end{array}$ \\
\hline \multicolumn{5}{|l|}{ Demographic controls } \\
\hline Black & $\begin{array}{r}-87 \\
(97)\end{array}$ & $\begin{array}{l}-36 \\
(96)\end{array}$ & $\begin{array}{l}-77 * * * \\
(23)\end{array}$ & $\begin{array}{l}-66 * * * \\
(23)\end{array}$ \\
\hline Hispanic & $\begin{array}{c}-199 * \\
(103)\end{array}$ & $\begin{array}{r}-162 \\
(102)\end{array}$ & $\begin{array}{l}-99 * * * \\
(24)\end{array}$ & $\begin{array}{l}-91 * * * \\
(23)\end{array}$ \\
\hline Never married & $\begin{array}{l}725^{* * * *} \\
(200)\end{array}$ & $\begin{array}{l}690 * * * \\
(201)\end{array}$ & $\begin{array}{r}70 \\
(44)\end{array}$ & $\begin{array}{r}62 \\
(44)\end{array}$ \\
\hline Divorced & $\begin{array}{l}485^{* * *} \\
(67)\end{array}$ & $\begin{array}{l}467 * * * \\
(66)\end{array}$ & $\begin{array}{l}71^{* * * *} \\
(14)\end{array}$ & $\begin{array}{l}67 * * * \\
(14)\end{array}$ \\
\hline \multicolumn{5}{|l|}{ Socioeconomic and health controls } \\
\hline Own years of education & $\begin{array}{l}161^{* * *} \\
(14)\end{array}$ & $\begin{array}{l}148 * * * \\
(14)\end{array}$ & $\begin{array}{l}38 * * * \\
(3)\end{array}$ & $\begin{array}{l}35^{* * * *} \\
\text { (3) }\end{array}$ \\
\hline Mother's years of education & $\begin{array}{l}-16 \\
(10)\end{array}$ & $\begin{array}{l}-18^{*} \\
(10)\end{array}$ & $\begin{array}{l}-2 \\
(2)\end{array}$ & $\begin{array}{l}-2 \\
(2)\end{array}$ \\
\hline Previous health limitations & $\begin{array}{l}-657 * * * \\
(58)\end{array}$ & $\begin{array}{l}-648 * * * \\
(57)\end{array}$ & $\begin{array}{l}-130 * * * \\
(13)\end{array}$ & $\begin{array}{l}-128 * * * \\
(12)\end{array}$ \\
\hline Lived in rural area as a child & $\begin{array}{l}-119 * \\
(61)\end{array}$ & $\begin{array}{l}-123^{* *} \\
(60)\end{array}$ & $\begin{array}{l}-36^{* * *} \\
(13)\end{array}$ & $\begin{array}{l}-37 * * * \\
(13)\end{array}$ \\
\hline Religion very important & $\begin{array}{l}-273^{* * *} \\
(87)\end{array}$ & $\begin{array}{l}-243 * * * \\
(87)\end{array}$ & $\begin{array}{l}-68 * * * \\
(18)\end{array}$ & $\begin{array}{l}-61^{* * *} \\
(18)\end{array}$ \\
\hline Constant & $\begin{array}{l}2,356^{* * *} \\
(348)\end{array}$ & $\begin{array}{l}2,546^{* * *} \\
(348)\end{array}$ & $\begin{array}{l}893 * * * \\
(70)\end{array}$ & $\begin{array}{l}934 * * * \\
(70)\end{array}$ \\
\hline Observations & 4,171 & 4,171 & 4,171 & 4,171 \\
\hline R-squared & 0.36 & 0.369 & 0.358 & 0.368 \\
\hline
\end{tabular}

Notes: AIMEs are in 2014 dollars. Each model also includes birth cohort dummies and indicator variables for women with missing information on: mother's education, growing up in a rural area, health limitations, religion, and years of education. Robust standard errors in parentheses. ${ }^{* * *} \mathrm{p}<0.01,{ }^{* *} \mathrm{p}<0.05,{ }^{*} \mathrm{p}<0.1$.

Source: Health and Retirement Study, 1992-2014. 
Table A2. Linear Regression Estimates of AIME and Social Security Benefits on Number of Children, Mothers Only, Detailed Results

\begin{tabular}{|c|c|c|c|c|}
\hline \multirow[t]{2}{*}{ Dependent variable } & \multicolumn{2}{|c|}{ AIME } & \multicolumn{2}{|c|}{ Social Security benefit } \\
\hline & $(1)$ & $(2)$ & $(3)$ & (4) \\
\hline \multirow[t]{2}{*}{ Number of children } & $-159 * * *$ & $-154 * * *$ & $-34 * * *$ & $-32 * * *$ \\
\hline & $(15)$ & (16) & (4) & (4) \\
\hline \multirow[t]{2}{*}{ Age at first birth } & & 6 & & 2 \\
\hline & & (9) & & $(2)$ \\
\hline \multirow[t]{2}{*}{ Young child living at home at age 62} & 257 & 245 & 60 & 57 \\
\hline & $(258)$ & (259) & (54) & (54) \\
\hline \multicolumn{5}{|l|}{ Demographic controls } \\
\hline \multirow[t]{2}{*}{ Black } & $241^{* * *}$ & $246 * * *$ & -4 & -3 \\
\hline & $(90)$ & $(90)$ & (23) & (23) \\
\hline \multirow[t]{2}{*}{ Hispanic } & -53 & -66 & $-75 * * *$ & $-79 * * *$ \\
\hline & (89) & $(90)$ & $(22)$ & $(22)$ \\
\hline \multirow[t]{2}{*}{ Never married } & -33 & -32 & $-126 * *$ & $-126 * *$ \\
\hline & $(184)$ & $(184)$ & (58) & (58) \\
\hline \multirow[t]{2}{*}{ Divorced } & $466 * * *$ & $474 * * *$ & $64 * * *$ & $66 * * *$ \\
\hline & (65) & (66) & (14) & (14) \\
\hline \multicolumn{5}{|l|}{ Socioeconomic and health controls } \\
\hline \multirow[t]{2}{*}{ Own years of education } & $123 * * *$ & $120 * * *$ & $31 * * *$ & $30 * * *$ \\
\hline & (13) & (14) & (3) & (3) \\
\hline \multirow[t]{2}{*}{ Mother's years of education } & -11 & -12 & -1 & -1 \\
\hline & (10) & (10) & $(2)$ & $(2)$ \\
\hline \multirow[t]{2}{*}{ Previous health limitations } & $-569 * * *$ & $-566 * * *$ & $-111 * * *$ & $-110 * * *$ \\
\hline & (54) & (54) & $(12)$ & $(12)$ \\
\hline \multirow[t]{2}{*}{ Lived in rural area as a child } & -89 & -86 & $-29 * *$ & $-28 * *$ \\
\hline & (56) & (56) & (12) & $(12)$ \\
\hline \multirow[t]{2}{*}{ Religion very important } & $-171 * *$ & $-173 * *$ & $-48 * * *$ & $-48 * * *$ \\
\hline & $(84)$ & $(84)$ & (18) & (18) \\
\hline \multirow[t]{2}{*}{ Constant } & $1,238 * * *$ & $1,112 * * *$ & $703 * * *$ & $669 * * *$ \\
\hline & $(342)$ & $(364)$ & $(74)$ & $(78)$ \\
\hline Observations & 3,822 & 3,822 & 3,822 & 3,822 \\
\hline R-squared & 0.239 & 0.239 & 0.271 & 0.271 \\
\hline
\end{tabular}

Notes: Social Security benefits are in 2014 dollars. Each model also includes birth cohort dummies and indicator variables for women with missing information regarding: their mother's education, growing up in a rural area, health limitations, the importance of religion, and her years of education. Robust standard errors in parentheses. *** $\mathrm{p}<0.01, * * \mathrm{p}<0.05, * \mathrm{p}<0.1$.

Source: Health and Retirement Study, 1992-2014. 


\section{RECENT WORKING PAPERS FROM THE CENTER FOR RETIREMENT RESEARCH AT BOSTON COLLEGE}

How Much Does Out-of-Pocket Medical Spending Eat Away at Retirement Income? Melissa McInerney, Matthew S. Rutledge and Sara Ellen King, October 2017

Can Knowledge Empower Women to Save More for Retirement?

Drew M. Anderson and J. Michael Collins, September 2017

Dementia, Help with Financial Management, and Well-Being Anek Belbase and Geoffrey T. Sanzenbacher, September 2017

The Behavioral and Consumption Effects of Social Security Changes Wenliang Hou and Geoffrey T. Sanzenbacher, September 2017

Family Transfers With Retirement-Aged Adults in the United States: Kin Availability, Wealth Differentials, Geographic Proximity, Gender, and Racial Disparities Ashton M. Verdery, Jonathan Daw, Colin Campbell, and Rachel Margolis, August 2017

Guardianship and the Representative Payee Program

Anek Belbase and Geoffrey T. Sanzenbacher, August 2017

The Relative Effects of Economic and Non-Economic Factors on Taxpayers' Preferences Between Front-Loaded and Back-Loaded Retirement Savings Plans Andrew D. Cuccia, Marcus M. Doxey, and Shane R. Stinson, July 2017

Social Security and Total Replacement Rates in Disability and Retirement Mashfiqur R. Khan, Matthew S. Rutledge, and Geoffrey T. Sanzenbacher, May 2017

An Experimental Analysis of Modifications to the Survivor Benefit Information within the Social Security Statement

Jeffrey Diebold and Susan Camilleri, May 2017

Actuarial Inputs and the Valuation of Public Pension Liabilities and Contribution Requirements: A Simulation Approach

Gang Chen and David S. T. Matkin, May 2017

Why Are U.S. Households Claiming Social Security Later?

Wenliang Hou, Alicia H. Munnell, Geoffrey T. Sanzenbacher, and Yinji Li, April 2017

Rising Inequality in Life Expectancy by Socioeconomic Status

Geoffrey T. Sanzenbacher, Anthony Webb, Candace M. Cosgrove, and Natalia S. Orlova, April 2017

All working papers are available on the Center for Retirement Research website (http://crr.bc.edu) and can be requested by e-mail (crr@bc.edu) or phone (617-552-1762). 